\title{
Placebo-controlled pharmacological trials in child and adolescents with bipolar disorder manic episode (BPD-ME): Systematic review, meta-analysis and a meta-regression on placebo response
}

\author{
Çocuk ve ergenlerde bipolar bozukluk manik epizodda (BPB-ME) plasebo \\ kontrollü ilaç çalışmaları: Sistematik derleme, meta-analiz ve plasebo yanıtı \\ üzerine bir meta-regresyon \\ Remzi Ogulcan Ciray ${ }^{1}$, Pelin Hancer2, Mustafa Tuncturk ${ }^{3}$, Neslihan Inal Emiroglu 4 \\ ${ }^{1}$ M.D., 4 Prof., Dokuz Eylul University Medical School, Child Psychiatry Department, Izmir, Turkey, https://orcid.org/0000-0003-2864-613X \\ https://orcid.org/0000-0003-3235-923X \\ 2M.D., Dokuz Eylul University Nursing School, Psychiatry Nursing Department, Izmir, Turkey, https://orcid.org/0000-0003-3857-7641 \\ 3 M.D., Bakirkoy Mazhar Osman Psychiatric Hospital, Psychiatry Department, Istanbul, Turkey, https://orcid.org/0000-0003-3928-3194
}

\section{SUMMARY}

Randomized placebo controlled trials (RCT) are very important for testing efficacy and safety of a medical treatment. There is no too much RCT's in childhood bipolar disorder manic episode. In these trials, high placebo response poses a problem for the definition of real drug responses in practice. Therefore, analysis of predictors of drug and placebo response are important for conducting more reliable RCT's in the future. Comprehensive search conducted in PubMed, ClinicalTrials.gov, Cochrane Central Register of Controlled Trials (CENTRAL) and some other electronic databases. Studies including participants with Bipolar Disorder manic episode and associated symptoms (e.g ADHD, irritability) included. There was no restriction in terms of sex, ethnicity or initial severity. Participants over age 18 were excluded. Random effect size model was used for calculate effect sizes for placebo and drugs.

A total of 1974 participants and 11 studies were included in the meta-analysis. Risperidone was highest effect size among drug arms. Number of the sites and number of the participants were associated with higher placebo response in meta-regression. We did not find any variable had an impact on drug response. There was no any publication bias in this meta-analysis. We found similar results as adult studies. Modifying number of the sites or ramdomized sample size may limit placebo response and could improve the efficacy of RCT's and enhance drugplacebo contrasts.

Key Words: Pediatric Bipolar Disorder, placebo response, meta-analysis, child and adolescent

\section{ÖZET}

Randomize plasebo kontrollü çalışmalar (RKÇ) tıbbi tedavilerin etkinliğini ve güvenliğini test etmekte çok önemlidir. Çocukluk çağı bipolar bozukluğun manik epizodunda yapılmış çok fazla RKÇ bulunmamaktadır. Bu çalışmalardaki yüksek plasebo yanıtı pratikte gerçek ilaç yanıtlarının tespitinde sorunlara neden olmaktadır. Bu nedenle ilaç ve plasebo yanıtının belirleyicilerini analiz etmek ileride daha güvenilir RKÇ'ler yürütebilmek için önemli olmaktadır. PubMed, ClinicalTrials.gov, Cochrane Central Register of Controlled Trials ve bazı diğer arama motorlarında geniş bir tarama yapıldı. Bipolar bozukluk manik epizod ve eşlik eden semptomlar(DEHB, irritabilite vb.) çalışmaya dahil edildi. Cinsiyet, etnisite ya da başlangıç şiddeti ile ilgili bir sınırlama getirilmedi. 18 yaşın üzerinde katılımcı olan çalışmalar dışlandı. Plasebo ve ilaç etki büyüklüklerini hesaplamak için random etki büyüklüğü modeli kullanıldı.

Toplamda 1974 katılımcı ve 11 çalışma meta-analize dahil edildi. Risperidon ilaç kolunda en yüksek etki büyüklüğüne sahipti. Meta-regresyonda merkezlerin sayısı ve katılımcıların sayısı yüksek plasebo yanıtıyla ilişkili bulundu. İlaç yanıtı etkileyen herhangi bir değişken bulunmadı. Meta-analizde herhangi bir yayın yanlığı tespit edilmedi. Çalışmada erişkin çalışmaları ile benzer sonuçlar bulundu. Randomize edilen katılımcı sayısını ve katılan merkez sayısını modifye etmek plasebo yanıtını sınırlayabilir ve RKÇlerin etkinliğini geliştirebilir ve ilaçplasebo farklılıklarını arttırabilir.

Anahtar Sözcükler: Pediatrik Bipolar Bozukluk, plasebo yanıtı, meta-analiz, çocuk ve ergen 


\section{INTRODUCTION}

Randomized controlled studies (RCTs) are gold standard clinical studies that are used to determine the efficacy and safety of drugs. Yet, many ethical, clinical or practical difficulties may be encountered during the design of these studies (1). Causes such as the cost burden of the studies, the heterogeneous nature of the diseases, the geographical differences, and the insufficient sample size may both complicate the conduction of the studies and alter or affect the response to placebo.

Placebo has been defined as "an attempt that is believed to be ineffective for a special medical treatment, or used to accelerate a medical treatment", or as "a treatment type used for its symbolic effect" (2). The placebo phenomenon was first used for pain perception and is still currently being studied (3). Theoretically, the effects of placebo have been described with classical conditioning, expectation and reward model theories. Many factors including the expectations of the physician and the patient, the color, the number and the administration route of the drugs used, the attitude of the physician and the patient characteristics have been advocated to be responsible for the placebo effect. The extent of the response to stimulants in life depends individually. The learned situations and the clinical appearance and biological structures of the individuals play a role on this situation. More complicated mechanisms such as changes in the emotional status, the motivation and cognitive functions play a role in the placebo response (4). Brain imaging techniques have also been used for investigation of the placebo response. Tonic activation of dopaminergic neurons in the dorsal striatum, ventral striatum and prefrontal cortex via positive expectations has been explained by efficacy of excitatory glutamate and inhibitory GABA impulses caused by placebo-derived reward expectation on dopaminergic neurons (5). Kemp et al. (2010) have explained the factors affecting the placebo response as delayed duration of studies, effects of rescue drugs such as sedation, insufficient optimization of drug doses, difficulties in compliance to the therapy or the study protocol, and different study designs (6). Other than that, financial support to participants and regression to the mean have been defined as causes that affect the placebo- drug difference. The drug-placebo difference may seem minimal due to the potential mediating nature of the disease severity, study populations including a higher number of patients with mild disease and the data obtained from these studies. RCTs have reported that the drug benefit possibility was higher among patients with previous severe symptoms (7). Recent meta-analyses have reported an increased placebo response among patients with acute schizophrenia within years, which has affected the drug-placebo differences as well (8). The same study demonstrates the importance of increasing the placebo response in studies within years as the only statistically significant parameter with industrial sponsorship. In the last 30 years, a reduction has been observed in the drug-placebo difference in antidepressant studies with the increase in the placebo response (9). Furthermore, certain characteristics such as the sample size and the study location have been significantly related to a higher placebo response in antidepressant studies. A statistically significant correlation has been determined between the placebo response and the number of institutes included in the study, age of the patients, percentage of male participants, year of publishing and the presence of psychotic findings in the meta-analysis of Yildiz et al. (2011) on the placebo response in bipolar manic attack (10). The study also demonstrates a higher possibility of pharmacological therapy response among young patients with bipolar disorder with a short duration of disease and lower possibility of the placebo response.

The majority of the studies conducted on the placebo response include adult participants. The studies mentioned above are dominantly those conducted on adults. The efficacy of psychiatric drugs (such as antidepressants) on children and adolescents may be different to the adult population. In a metaanalysis of antidepressant efficacy on children and adolescents, insufficient efficacy was determined except for fluoxetine, and an insignificant effect was observed in many of the drugs compared to placebo with a higher rate of side-effects (11). Additionally, in a clinical study investigating the placebo response in children and adolescents with anxiety disorder, no correlation was observed between the placebo response and age, gender, race or the diagnosis, but a positive correlation was 
determined with the acute period of the disease (12). ). In a review, bipolar disorder was observed to have a mixed features and a poor therapy response in children; thus, it was recommended that further studies should be conducted on the treatment and epidemiology of bipolar disease among children (13).

The placebo response and factors affecting the placebo response in children and adolescents have not been sufficiently investigated. Determining these factors could inform the design of future RCTs and optimize them to assess drug efficacy. Reducing the placebo response and optimizing the study design are important in bipolar disorder, which has a very heterogeneous symptomatology, especially in the manic episode of the disease, and designing randomized controlled studies due to its difficult nature caused by previously defined factors. There is no meta-analysis on the placebo response in the acute manic episode in children and adolescents. In this study, we aimed to help investigators design proper studies to minimize these factors.

\section{METHODS}

The review was conducted according to the PRISMA statement.

\section{Search strategy}

We searched electronic databases like PubMed, Medline, PsycINFO, Cochrane Library and Embase from January 1990 to July 2019. We used the following search terms: "Bipolar disorder", "adolescent", "young", "acute mania", "child", "randomized", "placebo controlled", "lithium", "risperidone", "quetiapine", "olanzapine", "haloperidol", "valproate", "ziprasidone", "aripiprazole", "lurasidone", "paliperidone", "zotepin”, "asenapine", "sertindole", "chlorpromazine", "thioridazine", "fluphenazine", "pimozide", "zuclopenthixol", clopenthixol", "clozapine". We tried to contact authors for additional information about some trials.

\section{Study design and participants}

Randomized placebo-controlled studies on children and adolescents (under 18 years of age) with the diagnosis of bipolar disorder type 1 manic episode (according to standardized diagnostic criteria, e.g. DSM-III, ICD-10 or newer versions) were included. The studies on the depressive episode of bipolar disease were not excluded. In addition, studies on adult populations (over 18 years of age), using not standardized diagnostic criteria, published before 1980 (DSM-III was published in 1980 and previous versions were not operationalized), including disorders other than bipolar disorder (more than $20 \%$ of the including participants), focusing on relapse prevention (stable patients) with less than 10 participants were excluded. Since the acute placebo response was analyzed, studies shorter than 18 weeks were included. No other limitations were implemented related to gender, ethnicity, severity of symptoms at the beginning or types of episodes (mixed, psychotic mania, pure mania) other than the age parameter. Studies using the standardized diagnostic tools (DSM-III, DSM-III-R, DSM-IV, DSM-IV-TR, DSM-5, ICD-10) on the diagnosis of manic episode of bipolar disease were included in the study. Disorders within the spectra of schizophrenia, accompanied by affective findings such as schizoaffective disorder were excluded. The studies on the depressive episode of bipolar disease were not included in the study. Disorders frequently accompanied by bipolar disorder such as ADHD and CD were also excluded. Studies focusing on stable patients (continuum studies or post-stabilization drug addition studies) were excluded. If the rate of comorbidities such as mental retardation or ADHD were more than $80 \%$, it was not included in the study for its intervening effect.

\section{Interventions and comparator}

Any type of pharmacological or supplement therapy was eligible irrespective of route of administration (oral, intramuscular, intranasal). All studies with fixed or flexible doses were included. Studies with a minimum duration of 7 days were included, whereas those with augmentation or recruitment therapies were not eligible. Psychosocial interven- 


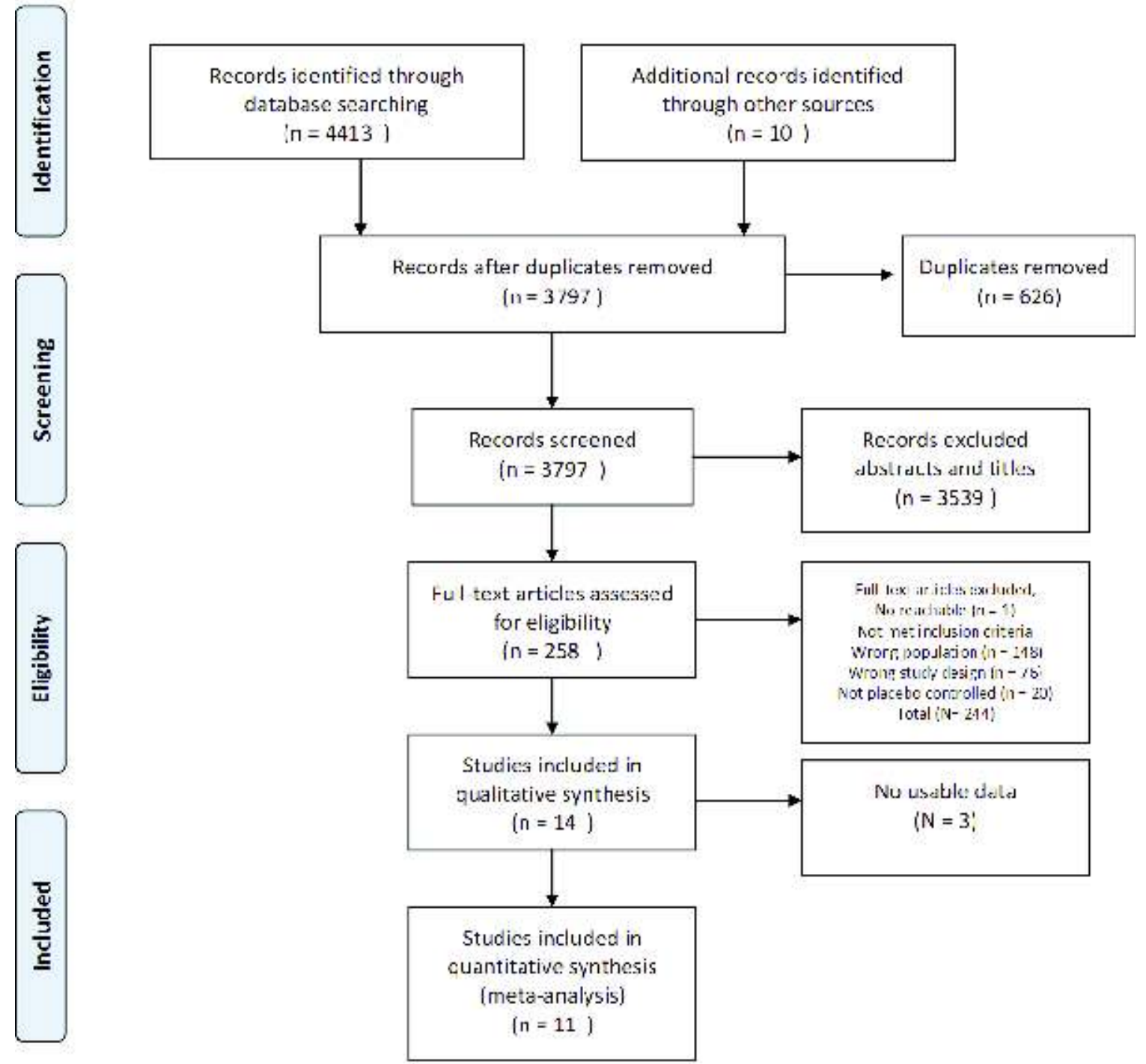

Figl: FRISMA lkw cin-1

tions, homeopathy, nutritional interventions (gluten-free diet, ketogenic diet etc.) were not eligible. The comparator was placebo.

\section{Type of Studies}

Placebo controlled, randomized studies conducted in the acute period of manic attack in bipolar disorder of children and adolescents were included in the study. In the case of a significant doubt on the randomization procedure, the study was excluded. No limitation was implemented for open and blinded studies. In cross-over studies, the first randomized and placebo controlled phase was included, while the post cross-over data were excluded.
Studies from all nations and all languages were accepted; however, the Chinese studies were excluded due to certain clinical concerns (14).). The risk of bias assessment was evaluated by a minimum of two reviewers (ROÇ and $\mathrm{PH}$ ) using the Cochrane Collaboration's risk of bias tool (15).

\section{Screening and Data Extraction}

Study selection against the inclusion criteria was done independently by three reviewers and they were blind each other (among, ROÇ, PH and MT). Conflicts were solved by the authors through discussion. NİH made last check and revisions. Subsequent to title selection, full-texts of the stu- 
dies to be included in the study were accessed. Fulltexts were read by two authors and those that met the inclusion criteria were included in the study. The data were extracted in excel and then checked by the second author (ROÇ and $\mathrm{PH}$ ). The authors were contacted for further information. In particular, data regarding the intention-to-treat (ITT) and the last observation carried forward (LOCF) were preferred during the data collection. Standard deviation not mentioned in the text was calculated according to the standard deviations of other studies (16).

\section{Outcomes}

We investigated change from baseline to endpoint in mania symptoms as measured by the Young Mania Rating Scale (17). The efficacy of drugs and supplements in reducing mania symptoms was also investigated.

\section{Statistical Analysis}

Meta-analysis using random-effects models were conducted for the efficacy of drugs or supplements and for the response in placebo arms (single group meta-analysis). The effect size for the efficacy of drugs compared with placebo was the standardized mean difference (SMD) as Hedge's g. Mean difference (MD) was used for the placebo response, since only one scale was used (YMRS) and the SMD of pre- and post- results is not recommended (18). Heterogeneity was assessed using the I2 and considerable heterogeneity was found when I2 $>=50 \%$. The focus of this review was predictors of placebo response and meta-regression analyses were performed. The variables were defined in table 2. Variables selected for meta-regression were preferred according to the propriety of the data in the studies and among parameters reported to be effective on the placebo response in the literature. Publication bias was assessed with the Egger test

\begin{tabular}{|c|c|c|c|c|c|c|c|c|c|c|c|}
\hline Study & $\begin{array}{l}\text { Drug/Number } \\
\text { of } \\
\text { participants }\end{array}$ & $\begin{array}{l}\text { Mean } \\
\text { Doses or } \\
\text { Range }\end{array}$ & $\begin{array}{l}\text { Duration } \\
\text { (weeks) }\end{array}$ & $\begin{array}{l}\text { In/Out } \\
\text { Patient }\end{array}$ & $\begin{array}{l}\text { Episode } \\
\text { type (mixt } \\
\text { or pure) }\end{array}$ & $\begin{array}{l}\text { Diagnosti } \\
\text { c criteria }\end{array}$ & $\begin{array}{l}\text { Countries/ } \\
\text { Study sites }\end{array}$ & $\begin{array}{l}\text { Number } \\
\text { of the sites }\end{array}$ & Age & $\begin{array}{l}\text { YMRS } \\
\text { Baseline } \\
\text { scores for } \\
\text { placebo } \\
\text { arm }\end{array}$ & Sponsorhip \\
\hline $\begin{array}{l}\text { DelBello } \\
2005\end{array}$ & $\begin{array}{l}\text { Topiramate } \\
n=29 \\
\text { Placebo } \\
n=27\end{array}$ & $278 \mathrm{mg}$ & 4 & $\begin{array}{l}\text { Outpati } \\
\text { ent }\end{array}$ & Both & DSM-IV & USA & 15 & $6-17$ & 29.9 & Sponsored \\
\hline $\begin{array}{l}\text { Wagner } \\
2006\end{array}$ & $\begin{array}{l}\text { Oxcarbazepin } \\
\text { e } \\
\mathrm{n}=59 \\
\text { Placebo } \\
\mathrm{n}=57\end{array}$ & $1515 \mathrm{mg}$ & 7 & $\begin{array}{l}\text { Outpati } \\
\text { ent }\end{array}$ & Both & DSM-IV & USA & 20 & $7-18$ & 28.8 & Sponsored \\
\hline $\begin{array}{l}\text { Tohen } \\
2007\end{array}$ & $\begin{array}{l}\text { Olanzapine } \\
\mathrm{n}=107 \\
\text { Placebo } \\
\mathrm{n}=54\end{array}$ & $10.7 \mathrm{mg}$ & 3 & $\begin{array}{l}\text { Outpati } \\
\text { ent }\end{array}$ & Both & DSM-IV & $\begin{array}{l}\text { USA, Porto } \\
\text { Riko }\end{array}$ & 26 & $\begin{array}{l}13- \\
17\end{array}$ & 32.04 & Sponsored \\
\hline $\begin{array}{l}\text { Wagner } \\
2009\end{array}$ & $\begin{array}{l}\text { Divalproex } \\
\text { ER } \\
\mathrm{n}=76 \\
\text { Placebo } \\
\mathrm{n}=74\end{array}$ & $1286 \mathrm{mg}$ & 3 & $\begin{array}{l}\text { Outpati } \\
\text { ent }\end{array}$ & Both & DSM-IV & USA & 24 & $\begin{array}{l}10- \\
17\end{array}$ & 31.3 & Sponsored \\
\hline $\begin{array}{l}\text { Haas } \\
2009\end{array}$ & $\begin{array}{l}\text { Risperidone } \\
\mathrm{n}=111 \\
\text { Placebo } \\
\mathrm{n}=58\end{array}$ & $0.5-6 \mathrm{mg}$ & 3 & $\begin{array}{l}\text { Outpati } \\
\text { ent }\end{array}$ & Both & DSM-IV & USA & 21 & $\begin{array}{l}10- \\
17\end{array}$ & 31 & Sponsored \\
\hline $\begin{array}{l}\text { Findling } \\
2009\end{array}$ & $\begin{array}{l}\text { Aripiprazole } \\
\mathrm{n}=195 \\
\text { Placebo } \\
\mathrm{n}=99\end{array}$ & $10-30 \mathrm{mg}$ & 4 & Both & Both & DSM-IV & USA & 53 & $\begin{array}{l}10- \\
17\end{array}$ & 30.7 & Sponsored \\
\hline $\begin{array}{l}\text { Findling } \\
2013\end{array}$ & $\begin{array}{l}\text { Ziprasidone } \\
\mathrm{n}=149 \\
\text { Placebo } \\
\mathrm{n}=88\end{array}$ & $106.6 \mathrm{mg}$ & 4 & Both & Both & DSM-IV & USA & 36 & $\begin{array}{l}10- \\
17\end{array}$ & 27 & Sponsored \\
\hline $\begin{array}{l}\text { Pathak } \\
2013\end{array}$ & $\begin{array}{l}\text { Quetiapine } \\
\mathrm{n}=188 \\
\text { Placebo } \\
\mathrm{n}=89\end{array}$ & $\begin{array}{l}400-600 \\
\text { mg }\end{array}$ & 3 & Both & Both & DSM-IV & USA & 34 & $\begin{array}{l}10- \\
17\end{array}$ & 30.7 & Sponsored \\
\hline $\begin{array}{l}\text { Kowatch } \\
2015\end{array}$ & $\begin{array}{l}\text { Risperidone } \\
\mathrm{n}=18 \\
\text { Valproat } \\
\mathrm{n}=21 \\
\text { Placebo } \\
\mathrm{n}=7\end{array}$ & $\begin{array}{l}\text { Risperido } \\
\text { ne }=0.5 \\
\mathrm{mg} \\
\text { Valproat } \\
=300 \mathrm{mg}\end{array}$ & 6 & $\begin{array}{l}\text { Outpati } \\
\text { ent }\end{array}$ & Both & DSM-IV & USA & 2 & $3-7$ & 30.57 & $\begin{array}{l}\text { Non- } \\
\text { Sponsored }\end{array}$ \\
\hline $\begin{array}{l}\text { Findling } \\
2015 \mathrm{a}\end{array}$ & $\begin{array}{l}\text { Asenapine } \\
\mathrm{n}=302 \\
\text { Placebo } \\
\mathrm{n}=101\end{array}$ & $5-20 \mathrm{mg}$ & 3 & $\mathrm{~N} / \mathrm{A}$ & Both & DSM-IV & $\begin{array}{l}\text { USA, } \\
\text { Russia }\end{array}$ & 86 & $\begin{array}{l}10- \\
17\end{array}$ & 30 & Sponsored \\
\hline $\begin{array}{l}\text { Findling } \\
2015 \mathrm{~b}\end{array}$ & $\begin{array}{l}\text { Lithium } \\
\mathrm{n}=53 \\
\text { Placebo } \\
\mathrm{n}=28\end{array}$ & $1483 \mathrm{mg}$ & 8 & $\begin{array}{l}\text { Outpati } \\
\text { ent }\end{array}$ & Both & DSM-IV & USA & 10 & $7-17$ & 30 & Sponsored \\
\hline
\end{tabular}


Ciray RO, Hancer P, Tuncturk M, İnal Emiroglu N.

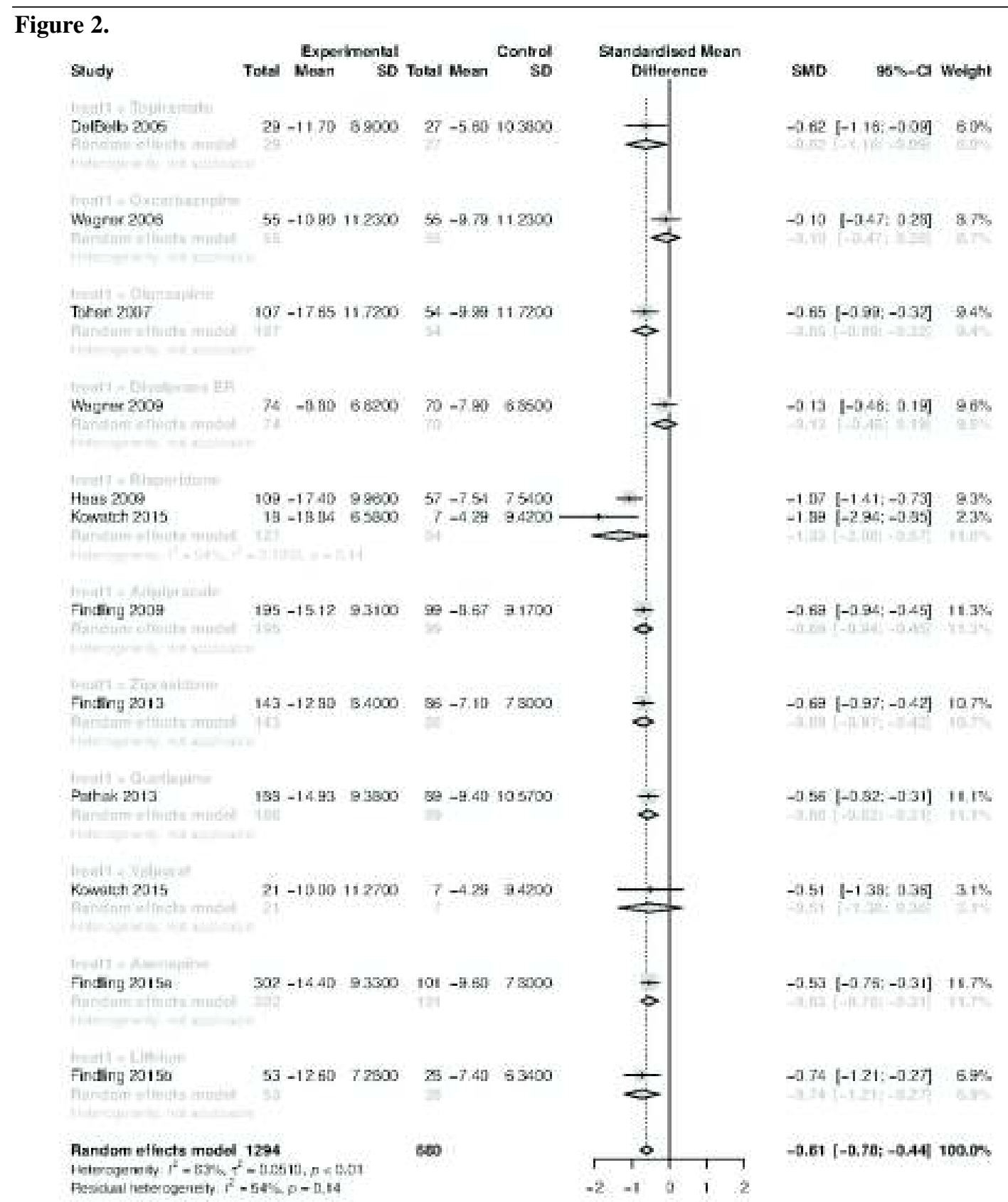

when more than 10 studies were available (19). For the data analyses, the meta and metaphor package $\mathrm{R}$ studio was used.

\section{RESULTS}

From 4423 studies found in the search, 11 were included in the study (20-30). PRISMA flow chart was showed in Figure 1. The study characteristics have been presented in Table 1. A total of $n=1974$ participants were included in 11 studies. Among these, $n=1294$ belonged to drug groups and $n=$

680 belonged to placebo groups. A study about Flax oil (31) was excluded in the analysis since the data of the scales were not proper. The bias risk was evaluated by two authors and demonstrated in table 4. Accordingly, all of the studies included at least one unclear moderate level of bias risk. The drug-placebo comparison has been demonstrated in Figure 2. Placebo response

The pooled mean difference of placebo response in YMRS was -8.30 (\%95 CI [-9.03; -7,56]) (Figure 3). Some heterogeneity was found but it was not considerable $(\mathrm{I} 2=\% 21, \mathrm{p}=0,24)$. 
Placebo-controlled pharmacological trials in child and adolescents with bipolar disorder manic episode (BPD-ME): Systematic review, meta-analysis and a meta-regression on placebo response

Figure 3. Drug efficacy
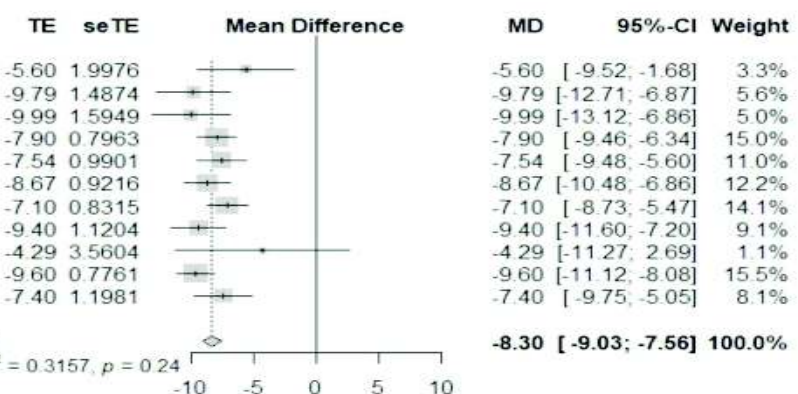

\section{Publication bias for placebo response}

All drugs except oxcarbazepine, divalproex ER and valproate, were found to be more effective than placebo in childhood acute mania. The effect size by pooling all drugs was medium $(\mathrm{SMD}=-0.61$, $\% 95$ CI $[-0.78,-0.44])$. The most effective drug in acute mania was determined to be risperidone. According to GRADE quality of evidence, certainty of the evidence of this meta-analysis was moderate (Table 3).

\section{Predictors of placebo response}

The results of meta-regressions are presented in Table 2. The number of centers $($ Beta $=-0.028, p=$ $0,038)$ and the sample size $($ Beta $=-0.007, p=0,034)$ were positively associated with placebo response (Figure 4; blue $=$ placebo arm, red $=$ drug arm $).$ It was observed as a result of drug group regression analyses that none of the variables had a significant effect on the drug response. No significance was determined for the mean age or age of disease onset ( $p=0.054$ and $p=0.0506$, respectively).
In order to evaluate the study tendentiousness, the Egger (Egger et al., 1997) test was performed and no tendentiousness was determined (19) $(p=0,55)$.

\section{DISCUSSION}

This study is the first meta-analysis to evaluate the placebo response and factors affecting the placebo response in the treatment of acute mania in children and adolescents. Our results are similar to a previous meta-analysis evaluating the placebo response in acute mania of adults revealed a higher placebo response in a) higher number of institutes included in the study and b) lower rate of male participants c) higher mean ages of the participants (10). In the same study, it was mentioned that psychotic characteristics could also be effective on the placebo response. The placebo response increased when number of the participant and number of the study centers increased. No significance was determined between the percentage of female gender and the placebo response (Table 2). The increased number centers could lead to diversity of the par-

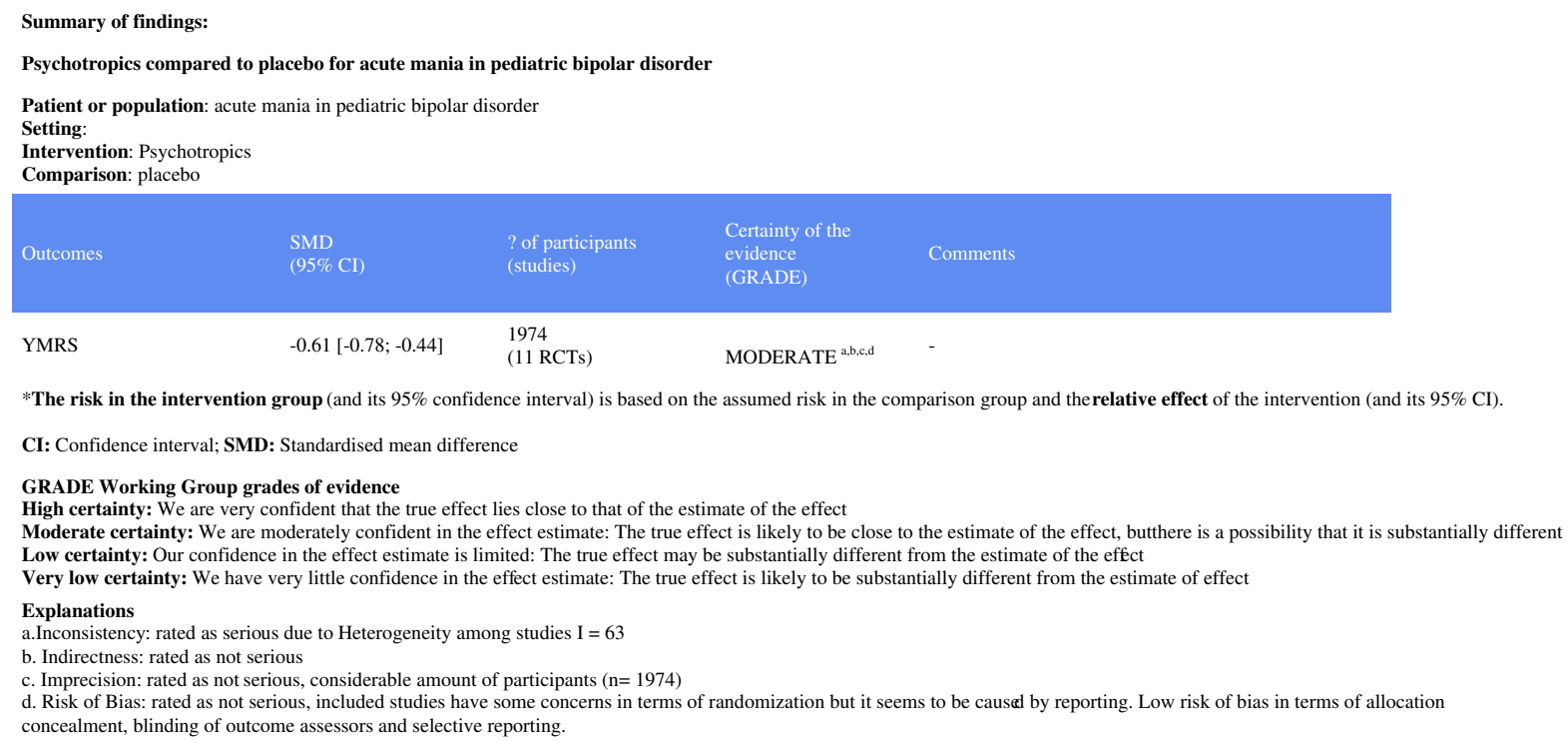

*The risk in the intervention group (and its 95\% confidence interval) is based on the assumed risk in the comparison group and therelative effect of the intervention (and its $95 \% \mathrm{CI}$ ). CI: Confidence interval; SMD: Standardised mean difference

GRADE Working Group grades of evidence

High certainty: We are very confident that the true effect lies close to that of the estimate of the effect

Moderate certainty: We are moderately confident in the effect estimate: The true effect is likely to be close to the estimate of the effect, butthere is a possibility that it is substantially different Low certainty: Our confidence in the effect estimate is limited: The true effect may be substantially different from the estimate of the effect

Very low certainty: We have very little confidence in the effect estimate: The true effect is likely to be substantially different from the estimate of effect

Explanations

a.Inconsistency: rated as serious due to Heterogeneity among studies $I=63$

b. Indirectness: rated as not serious

c. Imprecision: rated as not serious, considerable amount of participants $(n=1974)$

d. Risk of Bias: rated as not serious, included studies have some concerns in terms of randomization but it seems to be causel by reporting. Low risk of bias in terms of allocation concealment, blinding of outcome assessors and selective reporting.

Table 3. 
Figure 4.

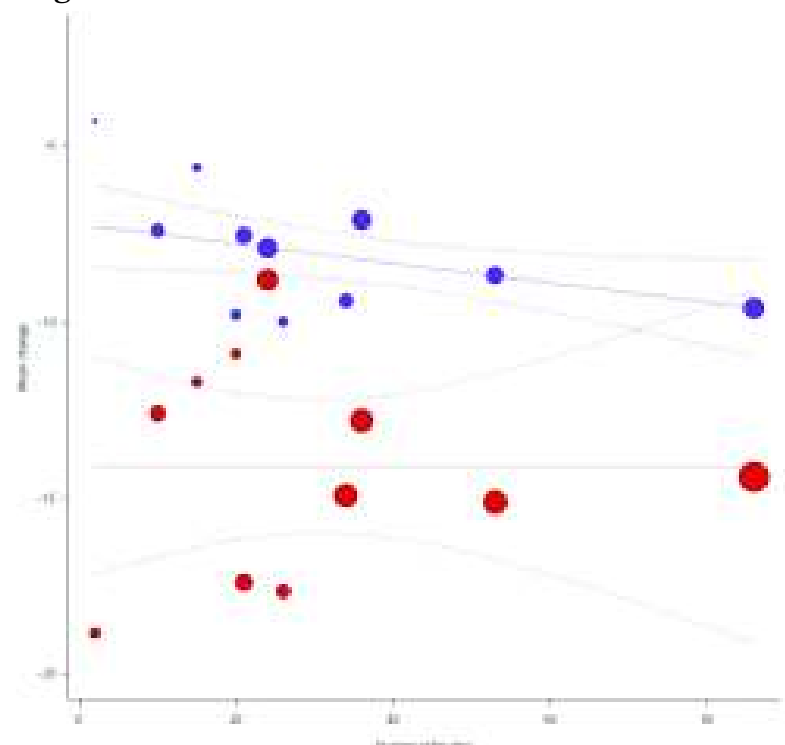

ticipants and scale scoring clinicians. This heterogeneity may affect the placebo response. It has been demonstrated in Table 2 that multi-center design and an increased number of participants could explain the heterogeneity, which was not considerable for placebo response $(\mathrm{I} 2=21 \%)$. Participants with mixed characteristics or pure mania may have different placebo responses. However, since pooled data are used in the study, these were not separated. Although borderline insignificance was observed for the age of disease onset $(p=0,0506)$, as the age of disease onset decreased, the placebo response seemed to decrease as well. This suggests that cases with early onset of the disease had a neuro-developmental background and were more difficult to treat. In our study, no effect of the study duration on the placebo response was detected. However, this may be due to the limitation of the study to the acute mania period only ( $<18$ weeks). It should be considered that the elapsed time may affect the placebo response due to the possibility of regression to the mean, and faster cycles of changes between emotional switches in children and adolescents.

Sponsorship were not associated with placebo response. However, a correlation was observed between the number of multi-center studies and the participants; most multi-center studies with large sample sizes had been conducted in the sponsorship of drug industries. Herein, the low number of studies included may be a problem. However, in the large-sample meta-regression study of Leucht

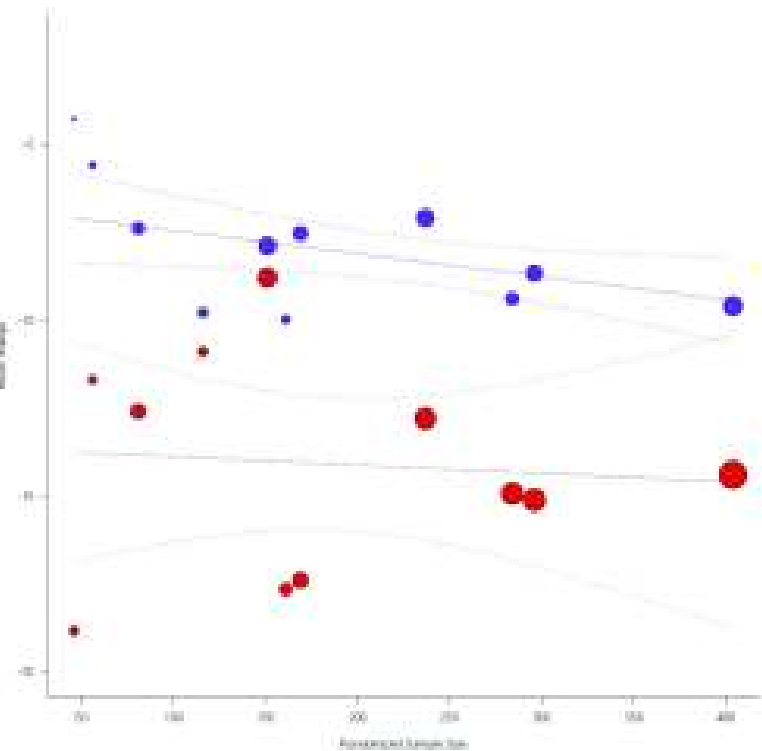

(2018), no correlation was found between industrial sponsorship and the placebo response (32). Although sponsorship is not a direct cause of bias itself, difficulties during procedures may change the placebo response. We found that the placebo response is not increased in time in contrast to adult studies (Table 2).

In our study, the placebo response was found to be high (See Figure 3). "Professional patients" should be added to the previously discussed causes. Generalizability would increase with the increase in the number of patients included accordingly. However, in multi-center studies with large sample size, the patients are selected via advertisements, and a group of patients is developed that provides livelihood from these studies. Altered motivations of these patients may affect the generalization of the placebo response to the universe (33).

Our study had some limitations. First, although a wide research was performed for the study inclusion, the number of placebo controlled randomized studies on children and adolescents is limited. Therefore, only 11 studies could be included. Furthermore, meta-regression analysis were suffered of poor statistical power due to the limited number of studies and their results should be interpreted with most caution and only as exploratory. Thus, we did not correct the threshold of statistical significance for multiple comparisons. The most powerful aspect of our study was that it was the first 
Table 4.

\section{As percentage (intention-to-treat)}

Overall Bias

Selection of the reported result

Measurement of the outcome

Mising outcome data

Deviations from intended interventions

Randomization process

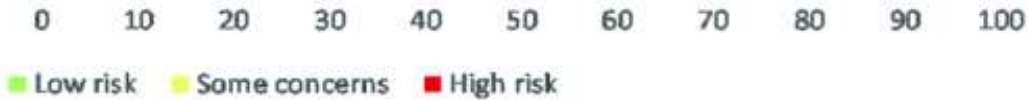

Trial ID

DelBello 2005

Wagner 2006

Tohen 2007

Wagner 2009

Haas 2009

Findling 2009

Findling 2013

Pathak 2013

Kowatch 2015

Findling 2015a

Findling 2015b

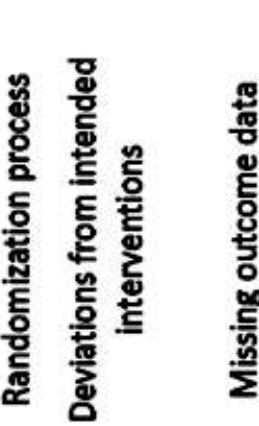

Weight

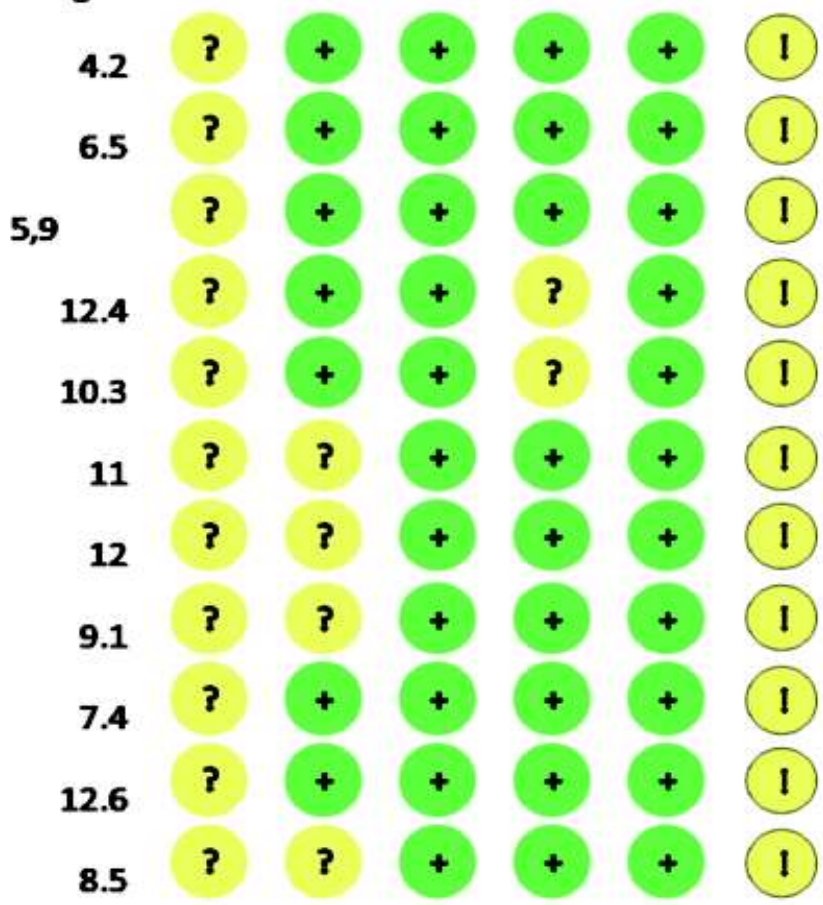


study to evaluate the placebo response and factors affecting the placebo response in acute mania observed in children and adolescents, and the most current meta-analysis on drug effects. The heterogeneous nature of the disease, the frequency of comorbidities, the difficulties in the study design and the time-dependent progression could not be bo response. The studies included in the study have revealed accompanying attention deficit, hyperactivity disorder, behavioral disorder, dissent and dispute disorder in most of the patients. Comorbid diseases may be a moderator to exert the placebo response and drug response. Sub-group analysis should be performed or the data set of each study should be accessed for this purpose. When it is considered that many comorbid diseases accompany bipolar disorder in children and adolescents, the symptoms of these diseases and mania may be confused and may change the scale scores.

\section{CONCLUSION}

Despite the limited number of studies, factors affecting the placebo response are similar to those with the adult studies. Further randomized, placebo controlled studies should be conducted on acute investigated and may play important roles in place-

mania in children. Modification of the placebo response is necessary for determining more accurate drug responses. Despite large placebo responses, the efficacy of the drugs in the manic episode of the children and adolescents with bipolar disorder is observed to be moderate-high.

\section{ACKNOWLEDGMENT}

R. Ogulcan Ciray would like to thank to Prof. Stefan Leucht and Dr. Spyridon Siafis for their mentoring and valuable suggestions.

\section{FUNDING}

This study was not supported by and institutions or company. Authors have no disclosures or conflicts.

Correspondence address: M. D. Remzi Ogulcan Ciray, Dokuz Eylul University Medical School, Child Psychiatry Department, Izmir, Turkey remziogulcanciray@gmail.com

\section{REFERENCES}

1. Charney DS, Nemeroff CB, Lewis L, Laden SK, Gorman JM, Laska EM, Borenstein M, Bowden CL, Caplan A, Emslie GJ, Evans DL, Geller B, Grabowski LE, Herson J, Kalin NH, Keck PE, Jr., Kirsch I, Krishnan KR, Kupfer DJ, Makuch RW, Miller FG, Pardes H, Post R, Reynolds MM, Roberts L, Rosenbaum JF, Rosenstein DL, Rubinow DR, Rush AJ, Ryan ND, Sachs GS, Schatzberg AF, Solomon S. National Depressive and ManicDepressive Association consensus statement on the use of placebo in clinical trials of mood disorders. Arch Gen Psychiatry. 2002;59:262-70.

2. Brody $\mathrm{H}$. The lie that heals: the ethics of giving placebos. Annals of internal medicine. 1982;97:112-8.

3. Beecher HK. The powerful placebo. Journal of the American Medical Association. 1955;159:1602-6.

4. Oken BS. Placebo effects: clinical aspects and neurobiology. Brain : a journal of neurology. 2008;131:2812-23.

5. de la Fuente-Fernandez R, Schulzer M, Stoessl AJ. Placebo mechanisms and reward circuitry: clues from Parkinson's disease. Biol Psychiatry. 2004;56:67-71.

6. Kemp AS, Schooler NR, Kalali AH, Alphs L, Anand R, Awad G, Davidson M, Dube S, Ereshefsky L, Gharabawi G, Leon AC, Lepine JP, Potkin SG, Vermeulen A. What is causing the reduced drug-placebo difference in recent schizophrenia clinical trials and what can be done about it? Schizophrenia bulletin.
2010;36:504-9.

7. Kirsch I. Antidepressants and the placebo response. Epidemiologia e psichiatria sociale. 2009;18:318-22.

8. Leucht S, Leucht C, Huhn M, Chaimani A, Mavridis D, Helfer B, Samara M, Rabaioli M, Bacher S, Cipriani A, Geddes JR, Salanti G, Davis JM. Sixty Years of Placebo-Controlled Antipsychotic Drug Trials in Acute Schizophrenia: Systematic Review, Bayesian Meta-Analysis, and Meta-Regression of Efficacy Predictors. Am J Psychiatry. 2017;174:927-42.

9. Khan A, Bhat A, Kolts R, Thase ME, Brown W. Why has the antidepressant-placebo difference in antidepressant clinical trials diminished over the past three decades? CNS neuroscience \& therapeutics. 2010;16:217-26.

10. Yildiz A, Vieta E, Tohen M, Baldessarini RJ. Factors modifying drug and placebo responses in randomized trials for bipolar mania. Int J Neuropsychopharmacol. 2011;14:863-75.

11. Cipriani A, Zhou X, Del Giovane C, Hetrick SE, Qin B, Whittington C, Coghill D, Zhang Y, Hazell P, Leucht S, Cuijpers P, Pu J, Cohen D, Ravindran AV, Liu Y, Michael KD, Yang L, Liu L, Xie P. Comparative efficacy and tolerability of antidepressants for major depressive disorder in children and adolescents: a network meta-analysis. Lancet (London, England). 2016;388:881-90. 
12. Strawn JR, Dobson ET, Mills JA, Cornwall GJ, Sakolsky D, Birmaher B, Compton SN, Piacentini J, McCracken JT, Ginsburg GS, Kendall PC, Walkup JT, Albano AM, Rynn MA Placebo Response in Pediatric Anxiety Disorders: Results from the Child/Adolescent Anxiety Multimodal Study. J Child Adolesc Psychopharmacol. 2017;27:501-8.

13. Emiroglu FN, Diler RS. Pediatric bipolar disorders: from the perspective of Turkey. Journal of the Canadian Academy of Child and Adolescent Psychiatry = Journal de l'Academie canadienne de psychiatrie de l'enfant et de l'adolescent. 2009;18:20614

14. Woodhead M. $80 \%$ of China's clinical trial data are fraudulent, investigation finds. BMJ (Clinical research ed). 2016;355:i5396

15. Higgins JPT AD, Sterne JAC. Cochrane handbook for systematic reviews of interventions version 5.2.0, Cochrane, 2017

16. Furukawa TA, Barbui C, Cipriani A, Brambilla P, Watanabe N. Imputing missing standard deviations in meta-analyses can provide accurate results. Journal of clinical epidemiology. 2006;59:7-10.

17. Young RC, Biggs JT, Ziegler VE, Meyer DA. A rating scale for mania: reliability, validity and sensitivity. Br J Psychiatry. 1978;133:429-35.

18. Cuijpers P, Weitz E, Cristea I, Twisk J. Pre-post effect sizes should be avoided in meta-analyses. Epidemiology and psychiatric sciences. 2017;26:364-8.

19. Egger M, Davey Smith G, Schneider M, Minder C. Bias in meta-analysis detected by a simple, graphical test. BMJ (Clinical research ed). 1997;315:629-34.

20. Delbello MP, Findling RL, Kushner S, Wang D, Olson WH, Capece JA, Fazzio L, Rosenthal NR. A pilot controlled trial of topiramate for mania in children and adolescents with bipolar disorder. J Am Acad Child Adolesc Psychiatry. 2005;44:539-47.

21. Wagner KD, Kowatch RA, Emslie GJ, Findling RL, Wilens TE, McCague K, D'Souza J, Wamil A, Lehman RB, Berv D, Linden D. A double-blind, randomized, placebo-controlled trial of oxcarbazepine in the treatment of bipolar disorder in children and adolescents. Am J Psychiatry. 2006;163:1179-86.

22. Tohen M, Kryzhanovskaya L, Carlson G, Delbello M, Wozniak J, Kowatch R, Wagner K, Findling R, Lin D, Robertson-Plouch $\mathrm{C}, \mathrm{Xu}$ W, Dittmann RW, Biederman J. Olanzapine versus placebo in the treatment of adolescents with bipolar mania. Am J Psychiatry. 2007;164:1547-56.

23. Wagner K, Redden L, Kowatch R, Wilens T, Segal S, Chang K, Wozniak P, Vigna N, Abi-Saab W, Saltarelli M, Wagner KD, Redden L, Kowatch RA, Wilens TE, Segal S, Chang K, Wozniak P, Vigna NV, Abi-Saab W, Saltarelli M. A Double-Blind, Randomized, Placebo-Controlled Trial of Divalproex ExtendedRelease in the Treatment of Bipolar Disorder in Children and Adolescents. Journal of the American Academy of child and Adolescent Psychiatry. 2009;48:519-32.

24. Haas M, Delbello MP, Pandina G, Kushner S, Van Hove I, Augustyns I, Quiroz J, Kusumakar V. Risperidone for the treatment of acute mania in children and adolescents with bipolar disorder: a randomized, double-blind, placebo-controlled study. Bipolar Disord. 2009;11:687-700.
25. Findling R, Nyilas M, Forbes R, McQuade R, Jin N, Iwamoto T, Ivanova S, Carson W, Chang K, Findling RL, Nyilas M, Forbes RA, McQuade RD, Jin N, Iwamoto T, Ivanova S, Carson WH, Chang K. Acute Treatment of Pediatric Bipolar I Disorder, Manic or Mixed Episode, With Aripiprazole: A Randomized, Double-Blind, Placebo-Controlled Study. Journal of Clinical Psychiatry. 2009;70:1441-51.

26. Findling R, Correll C, Nyilas M, Forbes R, McQuade R, Jin N, Ivanova S, Mankoski R, Carson W, Carlson G, Findling RL, Correll CU, Nyilas M, Forbes RA, McQuade RD, Jin N, Ivanova S, Mankoski R, Carson WH, Carlson GA. Aripiprazole for the treatment of pediatric bipolar I disorder: a 30-week, randomized, placebo-controlled study. Bipolar Disorders. 2013;15:138-49.

27. Pathak S, Findling RL, Earley WR, Acevedo LD, Stankowski J, Delbello MP. Efficacy and safety of quetiapine in children and adolescents with mania associated with bipolar I disorder: a 3-week, double-blind, placebo-controlled trial. J Clin Psychiatry. 2013;74:e100-9.

28. Kowatch R, Scheffer R, Monroe E, Delgado S, Altaye M, Lagory D, Kowatch RA, Scheffer RE, Monroe E, Delgado S, Altaye M, Lagory D. Placebo-Controlled Trial of Valproic Acid Versus Risperidone in Children 3-7 Years of Age with Bipolar I Disorder. Journal of Child and Adolescent Psychopharmacology. 2015;25:306-13.

29. Findling R, Landbloom R, Szegedi A, Koppenhaver J, Braat S, Zhu Q, Mackle M, Chang K, Mathews M, Findling RL, Landbloom RL, Szegedi A, Koppenhaver J, Braat S, Zhu Q, Mackle M, Chang K, Mathews M. Asena pine for the Acute Treatment of Pediatric Manic or Mixed Episode of Bipolar I Disorder. Journal of the American Academy of Child and Adolescent Psychiatry. 2015;54:1032-41.

30. Findling RL, Robb A, McNamara NK, Pavuluri MN, Kafantaris V, Scheffer R, Frazier JA, Rynn M, DelBello M, Kowatch RA, Rowles BM, Lingler J, Martz K, Anand R, Clemons TE, Taylor-Zapata P. Lithium in the Acute Treatment of Bipolar I Disorder: A Double-Blind, Placebo-Controlled Study. Pediatrics. 2015;136:885-94.

31. Gracious B, Chirieac M, Costescu S, Finucane T, Youngstrom E, Hibbeln J, Gracious BL, Chirieac MC, Costescu S, Finucane TL, Youngstrom EA, Hibbeln JR. Randomized, placebo-controlled trial of flax oil in pediatric bipolar disorder. Bipolar Disorders. 2010;12:142-54.

32. Leucht S, Chaimani A, Leucht C, Huhn M, Mavridis D, Helfer B, Samara M, Cipriani A, Geddes JR, Salanti G, Davis JM. 60years of placebo-controlled antipsychotic drug trials in acute schizophrenia: Meta-regression of predictors of placebo response. Schizophr Res. 2018;201:315-23.

33. Leucht S, Hierl S, Kissling W, Dold M, Davis JM. Putting the efficacy of psychiatric and general medicine medication into perspective: review of meta-analyses. The British journal of psychiatry : the journal of mental science. 2012;200:97-106. 